Home | Archives | About | Login | Submissions | Notify | Contact | Search

ES Home > Vol. 3, No. $1>$ Art. 3

Copyright $(1999$ by The Resilience Alliance*

Robinson, G. and J. Zappieri. 1999. Conservation policy in time and space: lessons from

divergent approaches to salvage logging on public lands. Conservation Ecology [online] 3(1): 3.

Available from the Internet. URL: http://www. consecol.org/vol3/iss1/art3/

A version of this article in which text, figures, tables, and appendices are separate files may be found by following this link.

\title{
Synthesis
}

\section{Conservation Policy in Time and Space: Lessons from Divergent Approaches to Salvage Logging on Public Lands}

\author{
George Robinson and Jeffrey Zappieri
}

\section{SUNY Albany}

- Abstract

- Introduction: Science and Conservation Policy

- The Storm and its Aftermath

- History of Land Use and Conservation in the Adirondacks

- Large-Scale Disturbances and the Adirondack Park

- Assessing the Potential for Adirondack Wildfires

- Legality of Tree Removal in the State Forest Preserve

- The Social and Economic Climate of the 1995 Blowdown

- Fire Management in the Adirondack Park

- Evolution of Science, Public Opinion, and Policy

- Contrasting New York and Northwestern States Salvage Logging Policy

- Conclusions

- Responses to This Article

- Acknowledgments

- Literature Cited

- Erratum (Added March 9, 1999)

\section{ABSTRACT}

A 50-yr precedent was reversed in 1995 when, following a powerful windstorm, salvage logging was disallowed in the protected Adirondack Park State Forest Preserve of New York, United States. Damage from a similar windstorm in 1950 had provoked massive salvage operations, approved by the New York State legislature on the grounds of fire prevention and resource conservation. Following the 1995 storm, state conservation officers and consulting ecologists were prepared with up-to-date assessment tools and a theoretical framework that treated large disturbances as normal ecosystem processes; the executive branch acted in accord with their recommendations to forgo salvage. Prior to these events in New York State, federal forest preserves in western states had recently been opened to salvage sales, following a widespread series of fires and insect outbreaks. In this latter case, under the rubric of "forest health," legislative amendments were added to unrelated bills and passed without open debate. This lack of public exposure may have denied opportunities for an ecological basis to a key policy decision that carries substantial ecological implications. On the one 
hand, Adirondack Park salvage policies have evolved to address large-scale forest disturbances as natural events rather than catastrophes that demand intervention. On the other hand, federal salvage policies have arisen in a different political and economic background, and have so far largely escaped scientific scrutiny.

KEY WORDS: Adirondack Park, forest disturbance, forest health legislation, public land use, salvage logging, science and public policy, wildfire, windstorm.

Published March 3, 1999.

\section{NTRODUCTION: SCI ENCE AND CONSERVATION POLICY}

In biological conservation, a key role for science in the policy process is providing timely information (Lubchenco 1995, 1998). Opportunities for ecologists can be especially significant following natural disasters, when the press and general public are likely to misjudge the resilience and resistance of natural systems. For example, during the 1998 Yellowstone fires, [See erratum.] when nearly one-fifth of the $9000-\mathrm{km}^{2}$ park was burning, the event was treated as a national catastrophe (Knight and Wallace 1989, Schullery 1989). However, evidence from dendrochronology suggests that severe droughts, accompanied by large wildfires, have previously occurred at intervals on the order of every 200 years (Romme and Despain 1989). One of the key difficulties for ecologists is getting this kind of information into the proper venues for influencing policy (Brunner 1995).

Current ecological theory stresses that natural systems are subject to stochastic, non-equilibrial processes (Boyce 1991, Pimm 1991, Sprugel 1991, Pickett et al. 1992, Shinneman and Baker 1997). Aligned with these changing viewpoints is the awareness that the areal extents of natural disturbances can be large enough to overwhelm whole communities and ecosystems, at scales larger than the sizes of many remnant natural areas (Rejmánek 1984, Baker 1992, Esseen 1994). The implications for biological conservation are strong, particularly with respect to the design and management of nature preserves (Laurance et al. 1997, Meffe and Carroll 1997). Powerful windstorms provide instructive examples of highly influential, large-scale natural disturbances that have both ecological and social dimensions (Turner et al. 1997). As with wildfires, they often call for rapid responses, but management options are usually limited to cleanup operations following the event. However, cleanup decisions drawn from an ecological perspective might emphasize that major disturbances contribute to natural ecosystem properties, leading to a policy of passive accommodation, rather than postdisturbance intervention (Peters et al. 1996).

In this paper, we search for connections between ecological science and public policy with respect to salvage logging on public lands. We examine how conservation policy was formulated in response to a massive 1995 windstorm in the Adirondack Park of New York State, an event that received little national attention, but gave rise to an ecologically informed precedent for addressing natural disturbances on protected public lands. The relatively large size of the Adirondack Park, its conservation status, and the extensive forest damage caused by massive windstorms in 1950 and 1995 combine to offer an instructive example of relationships between conservation goals and the scales of natural processes. The State's ultimate decision to forgo salvage logging in 1995 stood in stark contrast to contemporaneous national policies opening federal lands to salvage-related timber harvest.

We begin with a description of the storm event and the controversy that ensued. This is followed by a brief history of Adirondack Park management, including the significance of large-scale disturbances. We then explore the role of ecological theory and scientific information in the formulation of the policy response to the 1995 blowdown, which reversed a 50-yr standing precedent that had permitted salvage logging of highly protected Forest Preserve lands of New York State. We follow with a contrast between current New York State and federal salvage policies, drawing from recent debates over federal forest management for forest health in the Pacific Northwest.

\section{THE STORM AND ITS AFTERMATH}

In the early morning hours of Saturday, 15 July 1995, a fast-moving thunderstorm of near-record proportions traveled through the Adirondack Mountains of northern New York State. Moving from northwest to southeast, the storm, labeled a "derecho" by meteorologists, took a linear path with extensive lines of high-velocity microbursts (Fig. 1). Strong winds caused extensive damage, hitting hardest in northwestern counties of the Adirondack Park; approximately $4000 \mathrm{~km}^{2}$ of publicly- and privately-owned forest land were affected (J enkins 1995, DEC EAT 1996). The storm leveled trees, threatened lives and property, and raised the specter of catastrophic fires to follow. It was an event of major proportions that opened a floodgate of local opinion, although it received little attention from national media. 
Fig. 1. Thematic map of forest tree damage assessment in the Adirondack Park, New York State, following the July 1995 windstorm.

\section{Impact of Adirondack Storm of July 15, 1995}

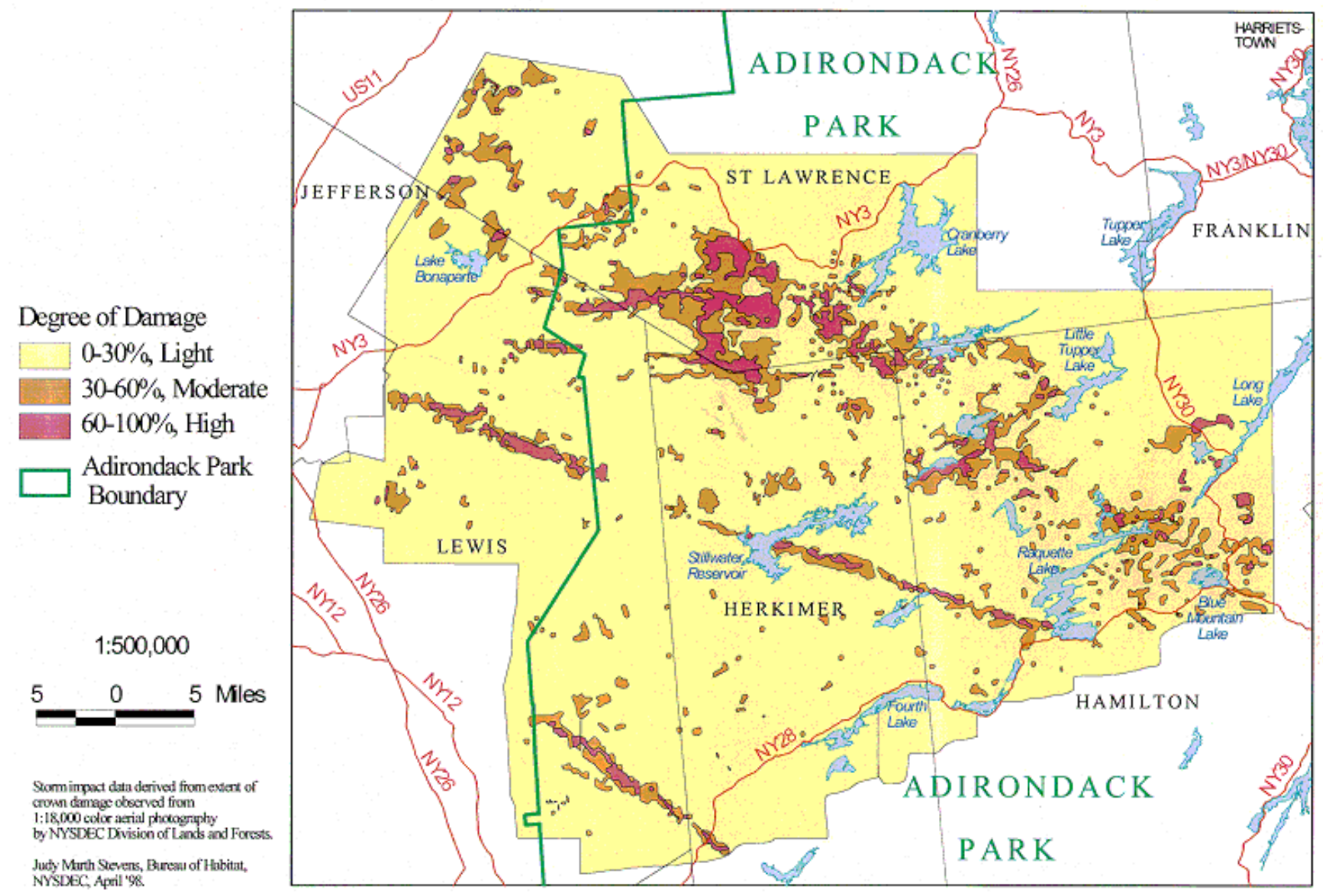

Adirondack residents were acutely aware of the storm and deeply worried about fire hazards during an unusually dry summer season. Spokespersons for wood products companies requested a prompt decision from the Governor allowing suspension of the State Constitution and permitting the authorization of salvage logging operations. In immediate response, environmental organizations protested salvage proposals on the grounds of state constitutional protections for the Park, fearing invocation of the salvage precedent that was set following a massive windstorm in the 1950s.

Numerous editorials and opinion pieces were published in the region's newspapers (Appendix 1). A common early theme was that fire danger was severe and the park was a "tinderbox ready to burn." Parallels were drawn to concurrent intense wildfires in the pine barrens of Long Island, New York. Adding to public fears was debate over the effectiveness of fire detection systems. Beginning in the 1980s, the New York State Department of Environmental Conservation (NYS DEC) had retired its lookout towers, relying instead on commercial and private pilots to report fire outbreaks. Some Park residents felt vulnerable and expressed support for salvage logging throughout the Park, to remove potentially hazardous fuel. 
Area, was nearly fireproof, dominated by water bodies and low-lying wetlands. Another theme was that, by opening dense forest canopies, large storms contribute to the Park's natural mosaic of habitats. Prominent among salvage opponents were the Adirondack Council, the Association for the Protection of the Adirondacks, New York's chapter of the National Audubon Society, the Natural Resources Defense Council, and the Wilderness Society (J enkins 1995; see Appendix 1).

The NYS DEC assembled a comprehensive document that included reports from an advisory committee of consulting ecologists (DEC EAT 1996). Based on scientists' recommendations and its own assessment of the consequences of storm damage, the agency concluded that salvage logging on protected lands could not be ecologically or economically justified. The Governor accepted the agency's recommendation, and a nosalvage decision was adopted, supporting the constitutionally guaranteed "forever wild" character of the Forest Preserve. New York conservation groups were quick to praise the decision, while parties that had pressed for salvage allowed the issue to die. In a few short months, a once-flaring debate had sputtered. It is worthwhile examining previous disputes over Adirondack lands and resources, in order to evaluate the response to the 1995 windstorm.

\section{HI STORY OF LAND USE AND CONSERVATI ON IN THE ADI RONDACKS}

The Adirondack Park, encompassing $24,280 \mathrm{~km}$ 2 of land within a designated protection zone (the "Blue Line"), is larger than the combined areas of Yellowstone, Glacier, and Olympic National Parks. Slightly over half of the park is privately owned, with the remainder belonging to New York State (Widmann and Drake 1997). Most of the public portion is designated as State Forest Preserve, a land use category accorded the highest degree of protection. The Forest Preserve is administered by NYS DEC, rather than by the Department of Parks and Recreation. The DEC's jurisdiction emerged from a lengthy debate over whether to emphasize the Park's recreational or environmental values (Graham 1978).

By 1825, 300 years after the explorer Champlain had laid plans for expeditions to settle the Adirondack region, New York was a populous, bustling state, while the Adirondacks remained inaccessible. Native Americans had created few, if any, permanent Adirondack settlements, and agriculture was limited to small, marginal operations. Land ownership had already passed among several nations, and land speculators had laid claim to substantial sections, even though the area was crudely mapped and poorly surveyed (Donaldson 1921, Graham 1978, Keller 1980, Pilcher 1987, McMartin 1994).

Like many of the remaining large natural areas, the Adirondacks had escaped human intrusion by default. In the meantime, nature conservation in New York State had become a public issue well before the founding of the Adirondack Park. New York's farmers had begun to notice a "rural decline," expressing concern over water pollution due to erosion and contamination by livestock, whereas trappers worried about the demise of beaver in northeastern North America (Whipple 1935, Graham 1978, Keller 1980). However, organized lobbying for protection of the Adirondack region first came from recreationists, whose numbers swelled following the publication of a popular travelogue (Murray 1869). These summer travelers were often greeted by the unpleasant landscapes that follow heavy logging, as timber operations expanded to feed a new and growing pulp market. George Perkins Marsh, one of the first advocates of an American wilderness ethic, lamented the environmental degradation caused by unregulated logging (Marsh 1864).

The major public policy issue that led to legal protection of Adirondack forests, however, was water quality. The 1885 Forest Preserve Law, which set the stage for founding the Adirondack Park in 1892, was aimed at protecting supplies of Adirondack fresh water, in part to maintain navigable flows in rivers and canals to the south. Other than the provision of a "Blue Line" boundary that encompassed some 1,130,000 ha of wildlands, there was little agreement on how to regulate and manage activities within the new Park. Indeed, at that time, only about 240,000 ha of the Park belonged to New York State. Eventually, forfeitures from tax delinquencies more than doubled these holdings (McMartin 1994). Most of the state-owned properties received a wilderness entitlement during the 1894 New York State Constitutional Convention. Article VII (7), which remains one of the strongest conservation documents in U.S. history, asserts: "The lands of the State, now owned or hereafter acquired, constituting the forest preserve as now fixed by law, shall be forever kept as wild forest lands. They shall not be leased, sold or exchanged, or be taken by any corporation, public or private, nor shall the timber thereon be removed or destroyed" (NY State Constitutional Convention 1894, Vol. V: 766, cited in Forsyth 1970). A Fisheries, Game and Forestry Commission was created to protect the area within the Blue Line by enforcing laws on public lands, and monitoring logging on private lands. (A glossary of acronyms and terms relevant to conservation of the Adirondack Park is presented in Appendix 2).

In subsequent years, attempts to reinstate commercial logging in the Forest Preserve were met by a concerted wilderness preservation lobby (Whipple 1935, Graham 1978). By 1935, on the 50th anniversary of the Forest Preserve, most state lands had been protected from extraction. Today, although much of the Preserve forest cover is second growth, the aging stands now include many large trees and incorporate ecosystem dynamics and wildlife populations characteristic of old-growth forests (Cogbill 1996, Dunwiddie et al. 1996). Recreational use grew rapidly after the Second World War, and sentiment for logging public lands 


\section{LARGE-SCALE DI STURBANCES AND THE ADI RONDACK PARK}

Hurricanes and other windstorms are among the most influential natural disturbances in forests of northeastern North America (e.g., Foster and Boose 1992, Foster et al. 1997). Now that post-agricultural regrowth has produced maturing forests with old-growth characteristics, evidence is mounting that the classic "gap" dynamic associated with single treefalls in temperate forests (Runkle 1981, Peet and Christensen 1987, Shugart 1987) is embedded in a broad and variable matrix of large-scale blowdowns, whose influence can extend over entire watersheds (Bormann and Likens 1979).

The western region of the Adirondacks appears to be prone to powerful windstorms, including tornadoes, hurricanes, and the lengthy chains of "microbursts" that descended in July 1995 (DEC EAT 1996). Windstorms are such a common occurrence that streets and towns in the region are occasionally named after them. The Great Blowdown of 25 November 1950 apparently caused more damage than any other storm in the history of New York State (Graham 1978, McMartin 1994, DEC EAT 1996). Accompanied by heavy rain, winds $>100$ mph $(45 \mathrm{~m} / \mathrm{s})$ rose from the southeast, beginning in New York Harbor and moving to the northwest. Tree root systems throughout the Adirondacks grow asymmetrically, against the force of prevailing westerlies, and blowdown was exceptionally widespread and devastating in the Park (Keller 1980, McMartin 1994). The dimensions of the total area of forest damaged by the storm were largely inferred from accounts of the volume of salvage timber removed. Some may have been poached opportunistically, whereas additional legitimate salvage may have been created by a later (1954) hurricane (McMartin 1994). The equivalent of $125 \times 10^{6}$ board feet (295,000 $\mathrm{m}^{3}$ ) of hardwood timber and nearly two billion board feet $\left(4.7 \times 10^{6} \mathrm{~m}^{3}\right)$ of softwoods was reportedly knocked to the ground. Aerial reconnaissance was limited, but a rough map of the damage indicates that $1600-1700 \mathrm{~km} 2$ ( 7\% of the current Park area) were "heavily affected, " with $25-100 \%$ of trees fallen or snapped (Graham 1978, DEC EAT 1996). Spruce (primarily red spruce, Picea rubens) was the most sought-after lumber tree and was also among the most heavily damaged (McMartin 1994).

At the time, warnings arose over the potential for catastrophic fires, due to the massive increase in fuel load. Foresters also feared that dead trees would invite disease and destructive insects of all kinds, arguing that insect species that attack dead or injured trees would also harm living ones (Graham 1978, McMartin 1994). Controversy ensued, with one contingent favoring immediate removal of the timber to prevent further timber losses, and another calling for a hands-off policy. Ultimately, emergency powers were invoked to suspend the State Constitution, permitting removal and sale of a large volume of timber (Graham 1978). During the 5yr salvage operation, approximately one million dollars accrued from the sale of public timber, with $10 \%$ of the proceeds being used to purchase additional Forest Preserve land (McMartin 1994).

\section{ASSESSI NG THE POTENTI AL FOR ADI RONDACK WI LDFI RES}

In their current extent and successional stages, Adirondack forests are unlikely to sustain large fires ( $\mathrm{J}$ enkins 1995). This is due to a moist summer climate and a landscape mosaic of frequent natural fire breaks, such as lakes, swamps, and rock outcrops. According to pre-settlement surveys taken in 12 townships in the western and northwestern Adirondacks during the period 1796 - 1825, fire was a rare event, of far less ecological importance than windstorms. Even in the more flammable sand plains and oak/spruce hills of the central and eastern Adirondacks, most historic fires are believed to have been of human origin, often fueled by logging debris. Throughout the Park, fire scars and charcoal are rare in old trees (Pyne 1984). A given conifer forest in the Adirondacks may burn naturally at intervals of 300 - $500 \mathrm{yr}$, whereas hardwood forest may burn at intervals of 1000 - 2000 yr (Bromley 1935, Henry and Swan 1974, DEC EAT 1996).

In the early days of the Park, fires fueled by logging debris were frequent and extensive. Legal provisions for fire control included a system of wardens, empowered to set penalties for deliberate burning on state property and to regulate railroad rights- of-way in the Preserve. In addition to ignition from railroad locomotives, it is believed that many fires were started in order to provide employment for temporary firefighters (Graham 1978). However, by the 1950s, forests had recovered sufficiently to regain much of their historic fire-retardant properties (McMartin 1994) and, in contrast to some expectations, the six years following the 1950 blowdown witnessed a total of 45 small fires, which in sum burned only 230 ha. Prolonged droughts were absent during this period, which was also a time of advances in early fire detection, including the use of aircraft, and improvements in fire suppression, with well-organized rapid-response teams (McMartin 1994). As a further precaution, fire-prone sites had been closed to campers and hikers, who remain, to this day, the major sources of ignition (DEC EAT 1996).

The post- 1950 salvage, which required suspension of the State Constitution, now seems unjustified on the basis of fire suppression. In fairness, we note that wildfire was still greatly feared at the time, and that tools for predicting fire potential were considerably weaker than those for fire suppression. At the same time, we can find 
no evidence of strong scientific opposition to the decision permitting salvage in the Forest Preserve. The legal profession, on the other hand, was well represented, as this unparalleled event quickly led to a renewal of historic debates over the meaning of "forever wild."

\section{LEGALI TY OF TREE REMOVAL IN THE STATE FOREST PRESERVE}

During the Constitutional Convention of 1915, the majority report of the Conservation Committee recommended the removal of dead trees to promote afforestation and fire protection, and to garner revenues. However, the "forever wild" clause has passed through two subsequent constitutional conventions (1933 and 1967) without substantial revision. Legal decisions affecting public forests in the Adirondack Park, primarily judicial dicta and Opinions of the Attorney General, have generally maintained a high level of protection for trees inside the Preserve. Early Attorney General rulings interpreted the "forever wild" clause literally and without exception. Appeals from wood products companies for access to dead and damaged Preserve trees were disallowed. Turn-of-the-century fires were blamed on lumbering practices, and public opinion had turned against commercial foresters. On the other hand, perceived fire threats led to decisions such as a 1933 Opinion that roads built for use in fire suppression did not violate constitutional protections. Fire, in fact, had become a touchstone in defining the legal meaning of "protection."

A landmark Attorney General's Opinion, which led to a suspension of the State Constitution, followed the hurricane of 1950 and established a precedent that was repeatedly invoked during debate over the appropriate response to a 1995 windstorm. On the grounds that the debris left by the storm constituted a fire hazard and, therefore, a threat to the Forest Preserve, the Attorney General ruled that cleanup was a legal and appropriate response to the perceived emergency. His Opinion also argued that fallen timber resources would help in the Korean War effort. A Constitutional amendment soon followed, and in a 5-yr progress report, the Attorney General's ruling was reaffirmed (Anonymous 1956). The 1950 Opinion stood as precedent for a large-scale salvage operation in the aftermath of the windstorm of 1995. The rush to salvage timber from Forest Preserve lands left bitter memories among conservation advocates, and later fueled efforts to convert the Adirondack Park to a National Park (Anonymous 1967, Graham 1978).

\section{THE SOCI AL AND ECONOMIC CLI MATE OF THE 1995 BLOWDOWN}

The wood products industry has historically been an important part of the Adirondack region's economy, today constituting $7 \%$ of the area's total revenues and about $10 \%$ of total economic activity (ESPFA 1995b). The current $2.4 \times 10^{6}$ ha Adirondack Park contains $1.4 \times 10^{6}$ ha of private lands, with ownership apportioned as: $26 \%$ large pulp and paper companies; $4 \%$ private clubs that manage and harvest their own forests; $28 \%$ small firms (including recreation and resource extraction industries); and 40\% individual families (Widmann and Drake 1997). State Forests, in contrast to State Preserve lands, are also managed for timber production. Table 1 summarizes NYS DEC's general estimates of the extent of blowdown effects on forest resources, characterizing storm damage as the percentage of trees damaged on different categories of forest land.

Table 1. Estimated land area affected by the 1995 Adirondack blowdown, categorized by jurisdiction and extent of wind damage. Data are from aerial photograph interpretation and market value estimation conducted by NYS DEC (DEC EAT 1996).

\section{Area of damage (ha)}

$\begin{array}{ccccc}\begin{array}{c}\text { Degree of } \\ \text { damage }\end{array} & \begin{array}{c}\text { Forest } \\ \text { Preserve }\end{array} & \begin{array}{c}\text { State } \\ \text { Forests }\end{array} & \begin{array}{c}\text { Private } \\ \text { lands }\end{array} & \text { Total }\end{array}$

Low $(0-30 \%) \quad 138,900 \quad 1250 \quad 194,500 \quad 334,650$




\begin{tabular}{lrrrr} 
Medium (30-60\%) & 25,300 & 850 & 15,900 & 42,050 \\
High (60-100\%) & 9700 & 600 & 5000 & 15,300 \\
Total & 173,900 & 2700 & 215,400 & 392,000 \\
$\begin{array}{l}\text { Estimated value } \\
\text { (\$US in millions) }\end{array}$ & $\$ 116.7$ & $\$ 3.0$ & $\$ 77.6$ & $\$ 197.3$ \\
& & & & \\
\hline
\end{tabular}

Within the Forest Preserve, the forest types most affected consisted of mixed hardwood/conifer stands managed as wilderness. NYS DEC estimated that only about $25 \%$ of the estimated salvage value ( $\$ 29$ million) could be recovered from the Preserve, due to impaired access, wood deterioration, and depressed timber markets. For privately owned lands, the Empire State Forest Products Association (ESFPA) predicted that $75 \%$ (6000 ha) of heavily damaged lands would be accessible (ESPFA 1995b). Assuming a net dollar loss before salvage of $\$ 2,700,000$, it was incumbent on private landowners to concentrate on recovering the value of their own fallen trees. The ESFPA sought guidance from the APA in clarifying regulatory ambiguities and requested that the Agency help landowners in their efforts to clean up the storm's aftermath. In response, the APA developed a general permit that clarified a landowner's legal obligations and allowed for an expedited review process, but still sought to maintain high environmental standards (DEC EAT 1996).

Salvage logging is generally an inefficient form of timber recovery. Experience from other regions where heavy storms have damaged forest lands (e.g., South Carolina after Hurricane Hugo; Pennsylvania after several recent tornadoes) shows that wood volume harvested accounts for $15-40 \%$ of the total available (Sheffield and Thompson 1992, ESPFA 1995a,b). The tangled stems and downed tops, often bent under extreme tension, promote hazardous working conditions. In addition, quality of the downed material is significantly reduced by breakage or shattering, insect damage, and fungal decay. In the Adirondacks, valuable species like white pine (Pinus strobus) and sugar maple (Acer saccharum) are susceptible to rapid degradation from fungal staining, and can lose commercial value within a few warm months (ESPFA 1995c).

In the economics of salvage logging, road building is probably the single greatest cost, and in blowdown areas, clearing exiting roadways and skidways increases the expense. In even the best of circumstances, new roads $>3 \mathrm{~km}$ in length are not cost effective (ESPFA 1995c). Logging roads also threaten the wilderness character of the Adirondack Park, and permits are difficult to obtain. In cooperation with NYS DEC, the Adirondack Park Agency (APA) has developed guidelines designed to minimize environmental impacts (McMartin 1989), and all of these practices add substantially to the costs of accessing downed timber in the park.

The economic climate for the Adirondack wood products industry differed substantially in 1950. The postWar American economy demanded abundant wood supplies, primarily to fuel a national housing boom, but also to fill increased demands of the paper industry (Sedjo and Radcliffe 1980). Although Adirondack forests were used largely for pulp production, the generally higher wood prices resulting from an economic boom encouraged salvage operations (Amigo and Neuffer 1980). In contrast, following the 1995 blowdown, a complex of economic factors combined to rule out a unified response from wood products industry advocates. With a glut of pulp wood and a weak market for new housing, demand was low for the damaged softwoods, and economical salvage operations would have been largely limited to hardwoods. However, because so much of the Park's private hardwood stands are relatively small parcels, a brief oversupply could have led to hardships for local landowners, who rely on a stable market, although thriving timber markets in Canada and Pennsylvania might have buffered price declines (ESPFA 1995c, DEC EAT 1996). As for loggers themselves, most independent operators are family businesses (K. Roy, personal communication), and they may have been sufficiently occupied with normal rotation harvests and salvage operations on private lands.

Despite a long-lasting animosity between Adirondack residents and State regulatory agencies (Graham 1978), no grassroots lobbying effort arose to promote salvage on Forest Preserve lands in 1995-1996. Furthermore, press accounts and letters to newspapers generally did not treat the blowdown as an unheard-of catastrophic event. Most opinion pieces in favor of salvage were the work of village administrators drawing attention to local fire hazards, and wood products industry advocates (Appendix 1). I ssues of forest health that had followed the 1950 hurricane were not raised, with the exception of one industry report (ESPFA 1995c). At the same time, state policy was formulated with a contemporary ecological perspective on the role of natural disturbance in forested ecosystems (DEC EAT 1996).

Ultimately, cleanup operations planned for the Park's wilderness areas were restricted to clearing woody debris 
from roads, trails, and campground facilities. Prompting this apparent change in policy was the argument that adding large amounts of recovered timber to a locally weak market would inevitably shift volume and value recovery away from private timberlands, thus reducing private-sector market opportunities. The prevailing counter-argument was the same one offered in 1950: that prohibiting public salvage operations would greatly enhance the hazard of forest fires. In scientific and management terms, the official policy for the Forest Preserve following the 1995 storm represented a near-complete reversal of the salvage precedent set after the 1950 hurricane. In addition to a changing socioeconomic climate, the 1995 event was distinguished from that in 1950 by the level of scientific effort directed at assessing wildfire potential.

\title{
FI RE MANAGEMENT IN THE ADI RONDACK PARK
}

Salvage logging after the 1950 blowdown was advocated by the Attorney General, on the grounds of fire prevention, and downed trees were treated as hazards to be removed. Memories of the 1903 and 1908 conflagrations were invoked (Graham 1978, McMartin 1994), and full-scale commercial access to Forest Preserve lands was permitted. By the time of the 1995 blowdown, however, the capacity to anticipate and respond to wildfires had improved. Assessment tools for fire potential were also much more advanced and accessible following the 1995 windstorm. NYS DEC had computer models at hand incorporating climate, topography, estimates of fuel loading, and variation in fuel moisture levels, as well as potential threats posed to dwellings and other structures (DEC EAT 1996). Advising in the use of these models were ecologists and environmental scientists from academic institutions and nongovernmental organizations. Decades of field study had demonstrated that most of the storm area was consistently humid, regularly supplied by moist air currents from the Great Lakes. The blowdown, however, did leave a high volume of elevated debris, which, upon drying, could act as potent fuel.

The "BEHAVE" model used in the 1995 assessment ranks fire potential numerically, based on fuel properties, with larger numbers indicating greater fire threat (DEC EAT 1996). Field sampling indicated that the fuel load had increased from an average of $19 \mathrm{Mg} / \mathrm{ha}$ (19 tons/ha) on unaffected sites to $70-350 \mathrm{Mg} / \mathrm{ha}$ on oldgrowth blowdown sites, with fuel reaching depths of $>12$ feet $(3.7 \mathrm{~m})$. Given this information, the fuel load portions of the model changed from classes 8-10 (characteristic of slow-burning surface fires of standing timber) to classes 11-13 (typical of quickly spreading, active-logging slash fires). Computer simulations using these classifications, along with matching slope gradients and a range of climate conditions, indicated that a wind-driven surface fire could enter an uncontrollable stage. For example, given wind speeds of 15 miles per hour $(24 \mathrm{~km} / \mathrm{h})$ and a fuel moisture level of $12 \%$ over a variety of slopes, the model predicted that fire behavior would exceed mechanical suppression efforts (DEC EAT 1996). However, judging from NYS DEC maps (Fig. 1) and APA satellite images (K. Roy, personal communication), much of the blowdown was very patchy and subdivided by numerous fire breaks.

Fire probability assessments of the 1995 storm undoubtedly benefited from a longer historical database, which included a period of more careful logging practices, improved regulation of recreational use, and the absence of steam locomotives from the Park. Between 1990 and 1995, 106 wildfires had been reported in the Five Ponds area, the region hardest hit by the 1995 windstorm. Those fires burned a total of 95 ha. Most originated with debris burning (32\%), campfires (13\%), and arson (20\%) (DEC EAT 1996). Because fires are more likely and more costly in areas of concentrated human activity, the more populous areas were designated by NYS DEC as focal points for fire prevention. The strategy proposed for these high-risk zones was to remove, reduce, or convert fuel types in order to lower fire hazards. Fire detection, suppression, and rescue capabilities were also stepped up in these locations, including the installation of new lightning detectors. In more remote areas of the Preserve, removal of downed trees was deemed unjustified, although flammable material was felled on some trails and campgrounds to promote decay (DEC EAT 1996).

\section{EVOLUTI ON OF SCIENCE, PUBLIC OPINION, AND POLICY}

\author{
Technological advances and improved understanding of ecological processes over the past half century have led \\ to greater opportunities for including science in the natural resources policy. Rapid and comprehensive \\ ecological assessments were key to the early formulation of a science-based response to the 1995 \\ Adirondack blowdown (DEC EAT 1996). Shortly after the windstorm's occurrence, NYS DEC officials were able \\ to obtain maps detailing the status of forest damage in various regions of the Park, products of modern \\ remote sensing and geographic information systems (GIS) technology that were unavailable in 1950 . These \\ analytical tools, in combination with knowledge extracted from large-scale surveys of key areas and long- \\ term monitoring projects in the Park, provided decision makers and conservation organizations with a \\ sophisticated and reliable information base.
}

Advancements in technology probably played other roles as well, including progress in fire hazard assessment and fire suppression capabilities since 1950, which also may have influenced policy choices. With a more 
accurate picture of the wind damage and better fire prediction and control tools, there was less incentive in 1995 than in 1950 for decision makers to focus management alternatives exclusively on wildfire potential. Ancillary social factors also may have played a part in reducing the fear of fire. Memories of the devastation caused by Adirondack forest fires in the early part of the century still existed in 1950, but had dimmed by 1995.

Changes in the sociopolitical realm between 1950 and 1995 have also been substantial. Throughout the 20th century, two schools of thought had dominated the American conservation policy field: resource conservation and environmental preservation (Callicott 1990). Proponents of resource conservation, or so-called "wise use," advocated efficient management of natural resources (Hays 1985). This view dominated public and political thinking until the 1960s (although it occupied a somewhat weaker position during the New Deal period of the 1930s), and experienced a resurgence in the 1980s. During the 1940s and 1950s, national emphasis was on the necessity for resource development at the cost of preservation, in order to achieve both prosperity (a reaction to the scarcity economics of the post-Depression era) and national security (a consequence of World War II and the subsequent rise of Cold War hostilities). Increased material abundance, enhanced by wartime technological advances, became the foundation for public policy decisions. Even liberal politicians, formerly strong supporters of New Deal concern over environmental preservation, stressed the practical and material benefits of developmental progress, afraid to appear "soft, naive, or utopian" in the new Cold War age (Koppes 1985). In 1944, Secretary of the Interior Chapman noted that conservation meant development of resources, not sequestering them from public and private use (Koppes 1985). Production for consumption, as opposed to the redistributive politics of the 1930s, was the theme of the Truman administration's Fair Deal program.

The late 1950s and 1960s witnessed a change in public values and demands, spurred on, in part, by increasing awareness of the consequences of environmental abuse (Costain and Lester 1995). Public values were also influenced by socioeconomic shifts in American society, as a majority of Americans began to look at natural areas more as sources of recreation than as sources of employment. The field of environmental issues at this time included concerns with open space, wildlands, and outdoor recreation (Dunlap 1995). These began to shape policy debate and constituted the initial political thrust for environmental preservation, culminating in the establishment of the National Outdoor Recreation Review Commission in 1958 (Hays 1985). The 1960s eventually saw the rise of environmentalism as a major social and political force. Nongovernmental environmental organizations (NGOs), which heretofore had limited impact on national politics, exhibited exponential growth. By the time of the 1995 blowdown, several NGOs, with local, state, and national memberships, were well-represented in the press and influential in the official NYS DEC assessment of the storm effects (Jenkins 1995, DEC EAT 1996, Appendix 1). Recent years have shown a return to more conservative politics and an upsurge in "wise-use" conservation policies on a national scale. Voters in environmentally progressive states, like New York, have displayed fewer of these tendencies, and with a contentious national election less than a year away, advocating salvage logging on public lands may have represented a political risk unacceptable to leading New York State officials.

Conservation biologists would like to believe that, despite the importance of political and economic factors, science has a significant role to play in public policy development. However, the political decision-making process is rarely dominated by ecological thought (e.g., Repetto 1993, Franklin 1995, Gunderson et al. 1995, Meffe and Carroll 1997). Policy is determined from an integrative analysis of all relevant factors, including, but certainly not limited to, rational assessment and scientific information (Brewer and DeLeon 1983). In order to clarify a role for science in this larger arena, a comparison of the 1995 Adirondack blowdown with comparable disturbance events elsewhere may be instructive.

\section{CONTRASTI NG NEW YORK AND NORTHWESTERN STATES SALVAGE LOGGI NG POLICY}

Significant turns in environmental public policy can follow a dramatic, highly publicized "focusing" event, such as the grounding of the Exxon Valdez in Prince William Sound, Alaska (Birkland 1998) or the Yellowstone wildfires of 1988 (Schullery 1989, Knight 1991). The Adirondack blowdown of 1995 received little media coverage outside northeastern New York, and it lacked the drama of blazing wildfires or oil-soaked wildlife. Although some local media reports were cast in rather sensational phrasing (Appendix 1), statewide attention was drawn to other natural resource issues, including wildfires in the Long Island Pine Barrens. In contrast, in northwestern states, the extensive wildfires of 1994 gave a sense of urgency to the salvage debate in federal forests. Perhaps the single most publicized event was the tragic deaths of firefighters during the Storm King Mountain fire (J oint Oversight Hearing 1995, Sampson et al. 1995). Combined with growing concerns about the cumulative damage of multiple pest outbreaks, fire-damaged trees were said to represent threats to "forest health." Large volumes of public lumber were opened for sale under the Emergency Salvage Timber Sale Program amendment to Public Law HR 104-19 (Section 2001, known as the "salvage rider").

Although the affected forests were disjunct units, and a comprehensive scientific assessment of damage was not conducted, salvage-based solutions were aimed at what some considered to be a general decline in northwestern forest health (Anonymous 1994, Blatner et al. 1994, Kolb et al. 1994, 1995, Morelan et al. 
1994, Sampson et al. 1994, 1995, DellaSala et al. 1995, DellaSala and Olson 1996). Congressional scrutiny was increasingly focused on fire management policy in northwest forests, in part because of growing concern over forest health issues, as well as threats posed by wildfires in expanding suburban zones (J oint Oversight Hearing 1995). Federal salvage legislation addressing forest health rested on what appeared to be a singleuse directive for public lands, in that future wood production was emphasized. Such utilitarian definitions of forest health may be satisfactory when a national forest is restricted to one or a few uses (high-yield production forest, or wilderness), but may break down in a multiple-use framework (O'Laughlin et al. 1994, Kolb et al. 1995, Peters et al. 1996). Therefore, despite its appeal, the concept of forest health remains ambiguous within the context of multiple, potentially conflicting, agency goals (O'Laughlin et al. 1994, Vogt et al. 1997).

Forest health assessments themselves may need better scientific grounding, including more comprehensive monitoring programs (O'Laughlin et al. 1994). Old-growth or otherwise unmanaged stands, for example, may require thinning to reduce fuel loads. In some cases, fire suppression has led to gradual changes in species composition in long-needled pine forests, leading to calls for combinations of fire management and salvage (Mutch 1992, 1994). However, unmanaged, aging stands can provide valuable wildlife habitat (e.g., Everett et al. 1994, Henjum et al. 1994, Torgersen and Bull 1995), and dead wood contributes to forest soil nutrient retention (Marton and Haire 1990). In the case of pest outbreaks, it can be debated whether a given infestation is an unusual, disruptive event or simply part of the natural disturbance regime of wild forests (Swetnam and Lynch 1989, Schowalter 1991, 1994, Wickman 1992). Amid these uncertainties, salvage logging on public lands was promoted without clear management goals or sound scientific bases (Peters et al. 1996). The politically polarized debate over salvage-based exemptions to federal environmental regulations may have slowed progress toward resolving these uncertainties (Blatner et al. 1994, Sampson et al. 1995, Peters et al. 1996).

The mixture of heavily forested public and private lands in both the Adirondack Park and the Pacific Northwest has led to some parallel resource management problems (FEMAT 1993, Blatner et al. 1994, Vogt et al. 1997). Indeed, the forest products industry briefly raised the issue of forest health following the 1995 Adirondack blowdown (ESPFA 1995b). Politically and economically, however, there are significant differences between the two regions that bear directly on forest management policy decisions. First, although the logging industry plays a prominent role in the Adirondack economy, there is no established industry presence in Preserve forests, because of the constitutional protection for the Forest Preserve. On the other hand, federal forests, which represent some of the largest properties in western states, began as extractive reserves.

Second, the state and federal resource agencies involved have missions and objectives that differ. NYS DEC is required to protect and balance the use of forest resources. The U.S. Forest Service and the Bureau of Land Management, in addition to comparable demands, are mandated to assure commercial production of forest products. As a means of encouraging forest harvest, these federal agencies subsidize the access costs of logging (Anonymous 1987). In the Adirondacks, industry pays for access. The strong timber lobby in the western states has been described as a "policy monopoly" (Berry 1989, Baumgartner and Jones 1993) because it is able to directly influence regulatory policy decisions. The condition is enhanced and strengthened, in this case, by the distributive nature of federal forest policy, in which tax moneys collected from the general public are spent on behalf of a small interest group. Distributive policies generally provide incentive for special interests to organize, and often encourage policy monopolization (Wilson 1973).

Third, budgetary constraints and agency jurisdiction are also important in solidifying the Forest Service's stance on salvage logging operations. A considerable portion of the Service's annual budget is devoted to expenses connected with conducting timber sales, including salvage operations (Rosenbaum 1995). For any Forest Service District, loss of salvage revenues could lead to decreased budget allowances and reduced stature and influence. Salvage sales are particularly desirable for financial reasons, because proceeds from salvage sales remain within the district, and cost accounting is less rigorous for salvage sales than for sales of standard rotation timber lots (Shields 1994). Non-salvage revenues revert to the agency's General Fund. A further incentive is found in a dedicated revolving fund, maintained by the Forest Service, from which districts may draw to cover costs of advertising and contract bidding. The fund's value increased $1,040 \%$ from 1987 to 1993 (Shields 1994). Salvage sales therefore contribute to a Forest Service District's stature and influence.

In the Adirondack Park, not only do state government agencies lack incentives to offer salvage sales, but also there is no large demand for public timber. The ESFPA represents a mixture of small and large industries that own timber lands, or are otherwise invested in long-term resource management. For many operators, salvage logging on State Forest Preserve property would have required abandoning ongoing operations, some of which had already expanded to include recovery of downed timber within private holdings. Furthermore, had demand for logs been higher, any political influence wielded by ESFPA might have been matched by a wellorganized environmental advocacy coalition.

Fourth, although the Adirondack Park is a single, largely contiguous management unit, regulated by environmental protection agencies, the forests targeted in Federal salvage legislation represent a broad mix of ecosystems with a wide range of management needs, including the need to define each unit's "multipleuse" mission within its respective agency (Cubbage et al. 1993). Adirondack Park administrators have had a century to struggle with definitions of multiple use, and the Park's current blend of public and private land use policy has evolved in response to changing public needs and attitudes. Many aspects of ecosystem 
management, such as adaptive management and hierarchical scaling (Jensen et al. 1996, Vogt et al. 1997), can be found in Adirondack Park directives (e.g., APA 1985, APA and NYS DEC 1985).

Finally, although the salvage decision in New York State was open to direct public scrutiny, legislation authorizing salvage on federal lands escaped public debate. The two federal salvage initiatives that passed were both amendments to public laws that were themselves unrelated to forest management policy (HR 104-19 in 1994 and HR 1158 in 1995). The single openly debated bill on the issue (S-391 in 1995) was never passed. Furthermore, the role of the chief executive was very different at each government level. In New York, taking the 1950 Adirondack blowdown response as precedent, no legislation to declare a constitutional emergency would have been introduced without an executive recommendation. Governor Pataki was identified as the primary decision maker, and lobbying was directed at the executive branch. At the federal level, President Clinton was handed legislation whose primary contents were popular and politically prominent programs (e. g., funding for emergency flood relief in California, in the case of HR 1158). At that stage, his only opportunity to act on the salvage amendments was a full veto. Furthermore, much of the lobbying directed against the salvage amendments began after their passage, whereas legislators sponsoring the amendments had previously received substantial election campaign contributions from wood products industries (Daly 1994).

\section{CONCLUSIONS}

A comparison of events surrounding the 1950 and 1995 Adirondack windstorms shows evident changes in public attitudes, applicable technology, ecological theory, and the role of science in public policy formulation. At the time of the 1995 storm, ecologists possessed an improved understanding of natural disturbance dynamics, and were also better positioned to inform policy decisions in New York State. Available new technologies (remote sensing, GIS, and fire assessment models) enhanced scientists' ability to convey necessary blowdown information to policy makers. An improved public understanding of ecological principles may have been instrumental in encouraging public and political acceptance of the necessity of maintaining natural disturbance regimes for forest ecosystems. It is likely that these factors, in combination, contributed to a societal climate conducive to greater scientific input in the policy process. However, under different socioeconomic and political circumstances, ecological science might have been given a smaller role, such as in the case of federal salvage logging in northwestern states. As general conclusions, we offer the following:

1) The Adirondack Park management system appears capable of accommodating large-scale natural disturbance as part of the forest fabric, without the need for intervention. To a large extent, this is unwritten policy, not explicit in the State Constitution and not sheltered from the winds of socioeconomic change. However, the decision to forgo potential resource benefits and to assume a moderate fire hazard risk, in exchange for allowing natural post-1995-blowdown recovery, has a firm basis in modern ecological theory.

2) Federal salvage policy in western states has largely escaped ecological scrutiny. We echo many others in noting that the wide range of ecosystems and the multiple management objectives of these various forests ought to produce a variety of salvage-related policy goals. Under current legislative mandates, however, a sciencebased salvage policy has not been effectively developed. Western forest ecologists may be poised to contribute significantly, but their expertise has been excluded from the decision-making process.

3) We stress that our treatment of western states' forest ecology and management has been superficial, and that the comparisons and contrasts we have drawn ignore innumerable details, ecological, political, and otherwise. However, we believe that fundamental differences in management have led to very different levels of public and scientific scrutiny, with consequences for the long-term protection of native forests.

\section{RESPONSES TO THIS ARTI CLE}

Responses to this article are invited. If accepted for publication, your response will be hyperlinked to the article. To submit a comment, follow this link. To read comments already accepted, follow this link.

\section{Acknowledgments:}

Assistance in researching this paper was provided by Gregory Austin, Jennifer Frank, Geoffrey Gardner, Julian Glos, Kimberly Hunsinger, Stefan Kaminsky, J oyce Lyons, April Magrane, Heather McCue, John Mercer, Marlene Sarjeant, Vera Thomas, Danielle Woodward, Nicole Wright, and Catherine Zoller. We are also grateful for the cooperation and assistance of many individuals in state government, the press, and academia, especially 
William Hammond, Edwin Ketchledge, Muriel Karp, Bill McKibben, David Morrell, Patricia Riexinger, Karen Roy, Cliff Siegfried, Thomas Stantz, Judy Stevens, and Richard Westergard. We thank Lori Quillen, Conrad Vispo, Margaret Stewart, and three anonymous reviewers for very helpful comments and recommendations for improvements. This manuscript represents the first in a series from the State University of New York at Albany Graduate Program in Biodiversity, Conservation, and Policy.

\title{
LITERATURE CITED
}

\author{
APA and NYS DEC (Adirondack Park Agency and New York State Department of \\ Environmental Conservation). 1985. Adirondack Park State Land Master Plan. APA, Ray Brook, New York, USA.
}

APA (Adirondack Park Agency). 1985. Adirondack Goals Program: final report on the Community Workshops. APA, Ray Brook, New York, USA.

Amigo, E., and M. Neuffer. 1980. Beyond the Adirondacks: the story of St. Regis Paper Company. Greenwood Press, Westport, Connecticut, USA.

Anonymous. 1956. Trends and developments in resources conservation: a five-year progress report of the New York State J oint Legislative Committee on Natural Resources. Williams Press, Albany, New York, USA.

. 1967. The Adirondacks, New York's Forest Preserve and a proposed National Park. New York State Conservation Department, Albany, New York, USA.

C., USA.

. 1987. State of the environment: a view toward the nineties. Conservation Foundation, Washington, D.

. 1994. Western forest health initiative. U.S. Forest Service, State and Private Forest

Program, Washington, D.C., USA.

Baker, W. L. 1992. The landscape ecology of large disturbances in the design and management of nature reserves. Landscape Ecology 7: 181-192.

Baumgartner, F. R., and B. D. J ones. 1993. Agendas and instability in American politics. University of Chicago Press, Chicago, Illinois, USA.

Berry, J. M. 1989. Subgovernments, issue networks, and political conflict. Pages 239-260 in R. M. Harris editor. Remaking American politics. Westview Press, Boulder, Colorado, USA.

Birkland, T. A. 1998. After disaster: agenda setting, public policy and focusing events. Georgetown University Press, Washington, D.C., USA.

Blatner, K. A., C. E. Keegan I I , J. O'Laughlin, and D. L. Adams. 1994. Forest health management policy: a case study for southwestern Idaho. J ournal of Sustainable Forestry 2: 317-337.

Bormann, F. H., and G. E. Likens. 1979. Catastrophic disturbance and the steady state in northern hardwood forests. American Scientist 67: 660-669.

Boyce, M. S. 1991. Natural regulation or the control of nature. Pages 183-208 in R. B. Keiter and M. S. Boyce, editors. The Greater Yellowstone ecosystem. Yale University Press, New Haven, Connecticut, USA.

Brewer, G. D., and P. DeLeon. 1983. The foundations of policy analysis. Dorsey Press, Homewood, Illinois, USA.

Bromley, S. W. 1935. The original forest types of New England. Ecological Monographs 5: 61-89.

Brunner, R. D. 1995. Notes on basic concepts of the policy sciences. Center for Public Research, University of Colorado, Boulder, Colorado, USA.

Callicott, J . B. 1990. Whither conservation ethics? Conservation Biology 4: 15-20.

Cogbill, C. V. 1996. Black growth and fiddlebutts: the nature of old-growth red spruce. Pages $113-125$ in M. B. Davis, editor. Eastern old-growth forests. Island Press, Washington, D.C., USA. 
Costain, W. D., and J. P. Lester. 1995. The evolution of environmentalism. Pages 15-38 in J. P. Lester, editor. Environmental politics and policy: theories and evidence. Duke University Press, Durham, North Carolina, USA.

Cubbage, F. W., J. O'Laughlin, and C. S. Bullock. 1993. Forest resource policy. Wiley, New York, New York, USA.

Daly, N. 1994. Timber PAC contributions to the U.S. Senate. Taxpayer Assets Project, Washington, D.C., USA.

DEC EAT (Department of Environmental Conservation Ecological Assessment Team). 1996. Response to the Adirondack windstorm of July 15, 1995: assessment report, recommended actions and appendices. March 1996, New York State Department of Environmental Conservation, Albany, New York, USA.

DellaSala, D. A., and D. M. Olson. 1996. Seeing the forests for more than just the trees. Wildlife Society Bulletin 24: 770-776.

DellaSala, D. A., D. M. Olson, S. E. Barth, S. L. Crane, and S. A. Pimm. 1995. Forest health: moving beyond rhetoric to restore healthy landscapes in the inland Northwest. Wildlife Society Bulletin 23: $346-356$.

Donaldson, A. 1921. A history of the Adirondacks. 1997 Edition, Century Company, New York, New York, USA.

Dunlap, R. E. 1995. Public opinion and environmental policy. Pages 63-114 in J. P. Lester, editor.

Environmental politics and policy: theories and evidence. Duke University Press, Durham, North Carolina, USA.

Dunwiddie, P., D. Foster, D. Leopold, and R. T. Leverett. 1996. Old-growth forests of southern New England, New York, and Pennsylvania. Pages 126-143 in M. B. Davis, editor. Eastern old-growth forests. Island Press, Washington, D.C., USA.

ESPFA. 1995a. Storm damage survey, August 8, 1995. Empire State Forest Products Association, Albany, New York, USA.

. 1995b. Survey of private timber losses from the July 15, 1995 storm. Empire State Forest Products Association, Albany, New York, USA.

. 1995c. Wave of Adirondack clearcutting? Hardly. Adirondack Cleanup is designed to protect health and productivity of private forests. December 1995, Empire State Forest Products Association, Albany, New York, USA.

Esseen, P.-A. 1994. Tree mortality patterns after experimental fragmentation of an old-growth conifer forest. Biological Conservation 68: 19-28.

Everett, R. L., P. F. Hesburg, J. Lemkuhl, M. Jensen, and P. Bourgeron. 1994. Old forests in dynamic landscapes. J ournal of Forestry J anuary: 22-25.

FEMAT (Forest Ecosystem Management Assessment Team). 1993. Forest Ecosystem Management: an ecological, economic and social assessment. U.S. Government Printing Office, Washington, D.C., USA.

Forsyth, A. S. 1970. The forest and the law. Sierra Club, New York, New York, USA.

Foster, D. R., J. D. Aber, J. M. Melillo, R. D. Bowden, and F. A Bazzaz. 1997. Forest response to disturbance and anthropogenic stress. BioScience 47: 437-445.

Foster, D. R., and E. R. Boose. 1992. Patterns of forest damage resulting from catastrophic wind in central New England, USA. Journal of Ecology 80: 79-98.

Franklin, J. F. 1995. Scientists in wonderland. BioScience 45: S74-S78.

Graham, F. 1978. The Adirondack Park: a political history. Alfred A. Knopf, New York, New York, USA.

Gunderson, L. H., S. S. Light, and C. S. Holling. 1995. Lessons from the Everglades. BioScience 45: S66-S73.

Hays, S. P. 1985. From conservation to environment: environmental politics in the United States since World War II. Pages 198-241 in K. E. Bailes, editor. Environmental history: critical issues in comparative perspective.

University Press of America, Lanham, Maryland, USA. 
Henjum, M. G., J. R. Karr, D. L. Bottom, D. A. Perry, J. C. Bednarz, S. G. Wright, S. A. Beckwitt, and E. A. Beckwitt. 1994. Interim protection for late-successional forests, fisheries, and watersheds: National forests east of the Cascades crest, Oregon and Washington. The Wildlife Society Technical Review 94-2, Bethseda, Maryland, USA.

Henry, J. D., and J. M. A. Swan. 1974. Reconstructing forest history from live and dead plant material: an approach to the study of forest succession in southwest New Hampshire. Ecology 55: 772-783.

Jenkins, J . 1995. Notes on the Adirondack blowdown of July 15th, 1995: scientific background, observations, and policy issues. Wildlife Conservation Society, New York, New York, USA.

Jensen, M. E., P. Bourgeron, R. Everett, and I. Goodman. 1996. Ecosystem management: a landscape ecology perspective. Water Resources Bulletin 32: 203-116.

J oint Oversight Hearing before the Committee and Natural Resources and the Committee on Agriculture, U.S. House of Representatives. 1995. Fire policy and related forest health issues (October 4, 1994). U.S. Government Printing Office, Washington, D.C., USA.

Keller, J. E. 1980. Adirondack wilderness, a story of man and nature. Syracuse University Press, Syracuse, New York, USA.

Knight, D. H. 1991. The Yellowstone fire controversy. Pages 87-103 in R. B. Keiter and M. S. Boyce, editors. Yale University Press, New Haven, Connecticut, USA.

Knight, D. H., and L. L Wallace. 1989. The Yellowstone fires: issues in landscape ecology. BioScience 39: $700-706$.

Kolb, T. E., M. R. Wagner, and W. W. Covington. 1994. Concepts of forest health. J ournal of Forestry J uly: 10-15.

Kolb, T. E., M. R. Wagner, and W. W. Covington. 1995. Forest health from different perspectives. Pages 4-13 in L. G. Eskew, editor. Forest health through silviculture. U.S. Forest Service, Rocky Mountain Forest and Range Experimental Station, General Technical Report RM-GTR-267.

Koppes, C. R. 1985. Environmental policy and American liberalism: the Department of the Interior, 19331953. Pages 437-475 in K. E. Bailes editor. Environmental history: critical issues in comparative perspective. University Press of America, Lanham, Maryland, USA.

Laurance, W. F., S. G. Laurance, L. V. Ferreira, J. M. Rankin-de Merona, C. Gascon, and T. E. Lovejoy. 1997. Biomass collapse in Amazonian forest fragments. Science 278: 1117-1118.

Lubchenco, J . 1995. The role of science in formulating a biodiversity strategy. BioScience 45: S7-S9. . 1998. Entering the century of the environment: a new social contract for science. Science 279: $491-497$.

Marsh, G. P. 1864. Man and nature. The Earth as modified by human action. 1970 edition. Scholarly Press, St. Clair Shores, Michigan, USA.

Marton, R. A., and D. H. Haire. 1990. Runoff and soil loss following the 1988 Yellowstone fires. Great PlainsRock Mountain Geographic Journal 18: 1-8.

McMartin, B. 1989. Citizens guide to Adirondack forestry. Adirondack Park Agency, Ray Brook, New York, USA. . 1994. The Great Forest of the Adirondacks. North Country Books, Utica, New York, USA.

Meffe, G. K., and C. R. Carroll. 1997. Principles of conservation biology. Second edition. Sinauer Associates, Sunderland, Massachusetts, USA.

Morelan, L. Z., S. P. Mealey, and F. O. Carroll. 1994. Forest health on the Boise National Forest. J ournal of Forestry August: 22-25.

Murray, W. H. H. 1869. Adventures in wilderness. 1970 edition, edited by W. K. Verner. Adirondack Mountain Museum, Blue Mountain Lake, New York, USA. 
Maryland, USA.

. 1994. Forest health and productivity: fire interactions. Proceedings of the Society of American Foresters National Convention: 101-106. Society of American Foresters, Bethseda, Maryland, USA.

O'Laughlin, J ., R. L. Livingston, R. Thier, J. Thornton, D. E. Toweill, and L. Morelan. 1994. Defining and measuring forest health. Journal of Sustainable Forestry 2: 65-85.

Peet, R. K., and N. L. Christensen. 1987. Competition and tree death. BioScience 37: 596-594.

Peters, R. L., E. Forst, and F. Pace. 1996. Managing for forest ecosystem health. Defenders of Wildlife, Washington, D.C., USA. URL posted April 1996:

Pickett, S. T. A., V. T. Parker, and P. L. Fiedler. 1992. The new paradigm in ecology: Implications for conservation biology above the species level. Pages 66-88 in P. L. Fiedler and S. K. Jain, editors. Conservation Biology. Chapman and Hall, New York, New York, USA.

Pilcher, E. 1987. Up the Lake Road, the first hundred years of the Adirondack Mountain Reserve. Centennial Committee for the Trustees of the Adirondack Mountain Reserve, Keene Valley, New York, USA.

Pimm. S. L. 1991. The balance of nature? University of Chicago Press, Chicago, Illinois, USA.

Pyne, S. J. 1984. Introduction to wildland fire. John Wiley, New York, New York, USA.

Rejmánek, M. 1984. Perturbation-dependent coexistence and species diversity in ecosystems. Pages $220-230$ in P. Schuster, editor. Stochastic phenomena and chaotic behaviour in complex systems. Springer-Verlag, Berlin, Germany, USA.

Repetto, R. 1993. Government policy, economics, and the forest sector. Pages 93-110 in K. Ramakrishna and G. M. Woodwell, editors. World forests for the future. Yale University Press, New Haven, Connecticut, USA.

Romme, W. H., and D. G. Despain. 1989. Historical perspective on the Yellowstone fires of 1988. BioScience 39: 695-699.

Rosenbaum, W. A. 1995. Environmental politics and policy. Congressional Quarterly, Washington, D.C., USA.

Runkle, J. R. 1981. Gap regeneration in some old-growth forests of the eastern United States. Ecology 62 : 1045-1051.

Sampson, R. N., D. L. Adams, S. Hamilton, S. P. Mealey, R. Steele, and D. Van Graffe. 1994. Assessing forest ecosystem health in the inland West. American Forests March/ April: 13-16.

Sampson, R. N., L. R. Clark, and L. Z. Morelan. 1995. Forest ecosystem health in the inland West. Pages 53-62 in L. G. Eskew, editor. Forest health through silviculture. U.S. Forest Service, Rocky Mountain Forest and Range Experimental Station, General Technical Report RM-GTR-267.

Schowalter, T. D. 1991. Roles of insects and diseases in sustaining forests. Proceedings of the Society of American Foresters National Convention: 262-267. Society of American Foresters, Bethseda, Maryland, USA.

. 1994. An ecosystem-centered view of insect and disease effects on forest health. Pages $189-195$ in U. $\bar{S}$. Forest Service Rocky Mountain Forest and Range Experimental Station, General Technical Report RM-247.

Schullery, P. 1989. The fires and fire policy. BioScience 39: 686-694.

Sedjo, R. A., and S. J. Radcliffe. 1980. Postwar trends in U.S. forest products trade: a global, national, and regional view. Johns Hopkins University Press, Baltimore, Maryland, USA.

Sheffield, R. M., and M. T. Thompson. 1992. Hurricane Hugo effects on South Carolina's forest resource. USDA Southeast Forest Experiment Station, Research Paper SE-284, Asheville, North Carolina, USA.

Shields, J . C. 1994. Timber Sale Program Information Reporting Service (TSPIRS): summary of the 1993 annual report. Center for Study of Responsive Law, Washington, D.C., USA.

Shinneman, D. J ., and W. L. Baker. 1997. Nonequilibrium dynamics between catastrophic disturbances and 
old-growth forests in ponderosa pine landscapes of the Black Hills. Conservation Biology 11: 1276-1288.

Shugart, H. H. 1987. Dynamic ecosystem consequences of tree birth and death patterns. BioScience 37: 596-602.

Sprugel, D. G. 1991. Disturbance, equilibrium, and environmental variability: What is 'natural' vegetation in a changing environment? Biological Conservation 58: 1-18.

Swetnam, T. W., and A. M. Lynch. 1989. A tree-ring reconstruction of spruce budworm history in the southern Rocky Mountains. Forest Science 35: 962-986.

Torgersen, T. R., and E. L. Bull. 1995. Down logs as habitat for forest-dwelling ants -- the primary prey of pileated woodpeckers in northeastern Oregon. Northwest Science 69: 294-303.

Turner, M. G., V. H. Dale, and E. H. Everham II I 1997. Fires, hurricanes, and volcanoes: Comparing large disturbances. BioScience 47: 758-768.

Vogt, K. A., J. C. Gordon, J. P. Wargo, D. J. Vogt, H. Asbjornsen, P. A. Palmiotto, H. J. Clark, J. L. O'Hara, W. S. Keaton, T. Patel-Weynand, and E. Witten. 1997. Ecosystems: balancing science with management. Springer-Verlag, New York, New York, USA.

Whipple, G. 1935. Fifty years of conservation in New York State, 1885-1935. New York State Conservation Department and New York State College of Forestry, Syracuse, New York, USA.

Wickman, B. E. 1992. Forest health in the Blue Mountains: the influence of insects and disease.U.S. Forest Service Technical Report PNW-GTR-295.

Widmann, R. H., and D. A. Drake. 1997. Forest resources on private land within the Adirondack Park. Adirondack J ournal of Environmental Studies 3: 11-18.

Wilson, J. Q. 1973. Organizations and public policy. Pages 327-346 in J. Q. Wilson, editor. Political organizations. Basic Books, New York, New York, USA.

\section{APPENDI CES}

Appendix 1. Chronology of selected newspaper and newsletter articles.

Craig, E.(1995, July 18). Killer storm hits County. Hamilton County News.

Egerman, J, (1995, July 11). Adirondack a tinderbox ready to burn. Hamilton County News.

Odell-Wilson, K. (1995, July 18). Assessing the damage. Adirondack Daily Enterprise.

Odell-Wilson, K. (1995, July 20). In wake of storm. Adirondack Daily Enterprise.

Hammond, W. (1995, July 30). State mulls whether to clear trees downed in Adirondack storm. Daily Gazette.

Associated Press (1995, August 7). Caught on a limb. Adirondack Daily Enterprise.

Russell, M. (1995, August 8). APA committee hears concerns over storm blowdown. Adirondack Daily Enterprise.

Hammond, W. (1995, September 3). Droughts bring potential for fire in Adirondacks. Daily Gazette.

Bryce, J. (1995, September 14). APA Plan would allow clear cutting critics say. Daily Gazette.

Hume, J. (1995, September 20). Don't rush to cut Adirondacks. Daily Gazette.

Anonymous. (1995, Fall). Powerful winds unearth new insights. The Nature Conservancy of New York Newsletter.

Russell, M. (1995, October 23). New York expected to scrap salvage plan for blowdown lands. Adirondack Daily Enterprise. 
Henry, G. (1995, November 30). The lowdown on the blowdown. The Chronicle.

Henry, G. (1995, November 30). Classic fight: Adirondack salvage on public lands. The Chronicle.

Regan, K. (1996, Winter) Blow Down! Natural disaster or ecological opportunity? The Flicker (Adirondack Nature Conservancy and Adirondack Land Trust).

Wise, J. (1996, January 21). Leave dead wood and risk Adirondack conflagration. Schenectady Sunday Gazette.

Anonymous. (1996, Spring). Governor's decision protects forests. Adirondack Council Newsletter, Elizabethtown, New York.

Gibson, D. H. (1996, August) Blowdown! Winds whip the north country. The Conservationist (NYS DEC).

Stevens, M. S. (1996, Fall) Blowdown in the Adirondacks. Wild Earth.

Appendix 2. Glossary of terms and acronyms.

The Adirondack Park consists of all land, state-owned and private, inside the Blue Line. The Park became a legal entity on 20 May 201892 by Chapter 707 of the laws of that year, stating that it was "... to be forever reserved, maintained, and cared for as a ground open for the free use of all the people for their health or pleasure, and as forest lands necessary to the preservation of the headwaters of the chief rivers of the state and a future timber supply." This law described the original Park boundaries, provided for the sale and exchange of land outside the Park, the expenditure of the proceeds for new purchases within the Park lines, and the leasing of campsites within the Park.

The Blue Line is the administrative boundary of the Adirondack Park. I ts name is derived from the fact that the State Comptroller in 1884 issued a map of the proposed park with the boundaries outlined in blue.

The Forest Preserve is a designation indicating the highest form of conservation in New York State, as described in the "forever wild" constitutional amendment adopted in 1894 (Vol. V, p. 766), which declares: "The lands of the State, now owned or hereafter acquired, constituting the forest preserve as now fixed by law, shall be forever kept as wild forest lands. They shall not be leased, sold or exchanged, or be taken by any corporation, public or private, nor shall the timber thereon be removed or destroyed." State lands in this classification are found in 12 Adirondack and four Catskill counties.

State Forests are public lands used as experimental or demonstration forests. They represent a small fraction of public Park lands, and are subject to commercial logging to generate revenues.

The Adirondack Park Agency (APA) is the independent New York State agency supervised by a board of commissioners, mandated to include Park residents. The agency, which has an advisory staff of scientists, planners, and lawyers, regulates land use practices within the Blue Line, mainly by issuing or denying permits.

The Empire State Forest Products Association (ESFPA) represents a consortium of private timber landholders in New York State. This group acts as a watchdog and participant in regulatory decisions affecting the Adirondack Park. Members include private land owners, paper companies, lumber companies, furniture manufacturers, and saw mills.

The New York State Department of Environmental Conservation (NYS DEC) is the agency charged with management of the Adirondack Park. This agency also regulates and monitors environmental quality, including air, waters, forests, fisheries, and wildlife, throughout the state.

\section{Address of Correspondent:}

George Robinson

Department of Biological Sciences

Biology 126

State University of New York at Albany

Albany, NY 12222 USA

Phone: (518) 442-4302

Fax: (518) 442-4767

grobins@csc.albany.edu 
*The copyright to this article passed from the Ecological Society of America to the Resilience Alliance on 1 J anuary 2000.

Home | Archives | About | Login | Submissions | Notify | Contact | Search 